\title{
Attitude of College Teachers towards the Utilization of Language Laboratories for Learning English
}

\author{
Dr. E. Ramganesh ${ }^{1} \&$ S. Janaki ${ }^{1}$ \\ ${ }^{1}$ Dept. of Educational Technology, Bharathidasan University, Tiruchirappalli, Tamilnadu, India \\ Correspondence: S. Janaki, Ph.D. Research Scholar, Dept. of Educational Technology, Bharathidasan University, \\ Tiruchirappalli 620023. Tamilnadu, India.
}

Received: January 29, 2017

Accepted: February 22, 2017

Online Published: March 8, 2017

doi:10.20849/ajsss.v2i1.120

URL: https://doi.org/10.20849/ajsss.v2i1.120

\begin{abstract}
With globalization, there has been a rise in demand for employees with good communication skills. With the growing demand for excellent communication skills, there have been explorations in the area of technology to meet this purpose. And one such experiment has been in the field of language laboratory (Smiriti singh, 2014), which is an instructional technology tool consisting of a source unit that can disseminate audio materials to any number of students at individual seats. The purpose of this study is to investigate teachers' attitude towards the utilization of Language laboratories for learning English. The respondents in this study are sixty English language teachers from different types of colleges. A descriptive method with a survey technique was adopted. The findings of this study reveal that the teachers have a positive attitude towards the use of Language laboratories in an ESL classroom. Also, this study infers that students seemed have high motivation when Language laboratories are used in the ESL classroom.
\end{abstract}

Keywords: attitude, college teachers, utilization, language laboratory

\section{Backdrop of the Study}

A typical audio-lingual language lab activity is one in which students listen to and repeat pre-recorded audio materials, either individually or as a group, with the option of the teacher "monitoring" (listening without disturbing the students) and providing individual feedback as necessary. Language acquisition theories, however, have changed significantly from the days when language labs ruled as the pre-eminent technology in language instruction (Baltra, 1986). As the result of this change, the language lab came to be seen as a relic with no merit in today's language learning environment. (Rivers, 1987)

Language labs are adequate places where a learner can undergo self-learning experience at his own pace, by practicing a host of exercises through technology. These exercises can be done in all the four modalities of language learning (Smriti, 2014). Many researchers have helped develop the theory and practice the Communicative Language Teaching Approach (Brown, 1987; Brumfit \& Johnson, 1979; Hymes, 1972; Nattinger, 1984; Nunan, 1987 \& 1989; Richards \& Rodgers, 1986; Rossner, 1988; Savingnon, 1983; White, 1989; Yalden, 1983). The underlying theory of the CLT approach is the communicative competence (Hymes, 1972). Students do not simply learn the linguistic structures and grammar rules. They have to learn how to use the language properly. Littlewood, (1981) described the CLT approach that one of the most characteristic features of communicative language teaching is that it pay systematic attention to functional as well as structural aspects of language. In reaction to the grammar-translation and audio-lingual methods, the CLT approach emphasizes the communicative activities that involve the real use of language in daily life situation

In India, English is not used only for the utilitarian purpose but also for the interpersonal and inter-institutional communication. It works as the Business Language as well as the Lingua Franca, which means that it is required to carry out the business and also to communicate with people of different cultures as India is a multi-cultural and multi-lingual country. It is no more working as the status language of the elite class or the educated class of the society, rather it is working as an instrument to bring success in life. The youth of India are aware that English can win them good jobs with rich salary if they are good in English. Gardner, Lambart and Smythe (1979) have done extensive research on attitude and motivation and their co-relation with linguistic performance of learners. They suggested that an L2 (English as second language) learner needs to be psychologically prepared to acquire a second or a foreign language as it is a part of different ethno-linguistic community. An L2 learner is 
required to impose elements of another culture into one's own life space (Khanna \& Agnihotri, 1994). Therefore, he needs to be psychologically prepared. In that way the present investigation is attempted to study the attitude in three different dimensions, towards learning English.

\subsection{Teachers' Attitude}

Attitude can be defined as a set of beliefs developed in a due course of time in a given socio cultural setup. It is studied that positive attitude facilitates learning. Teachers' attitude plays an important role in the present context. At the graduation level, teachers' have changed their role from being the controller of the class to the facilitator. They accept students' mistakes in the language use as a necessary part of the language learning. They help and motivate students use more and more language in their daily life. Learners learning outcomes are influenced by the interpretation of teachers' interpersonal behaviour.

\subsection{Teachers' Role}

With the age of paradigm shift, the teacher has to come a long way from being a strict disciplinarian to a facilitator. The teacher needs to make them realize that he/she is the one like them who also commits mistakes in the use of English and mistakes are a natural part of learning a language (Meenakshi H. Verma, 2005).

\section{Objective of the Study}

The study attempts to achieve the following objectives:

1) To investigate teachers' attitude towards the utilization of language laboratories in ESL classrooms.

2) To find out teachers' attitude towards the utilization of language laboratories in ESL classrooms on Affective, Cognitive and Co-native aspects.

3) To evolve policy decisions on the basis of the findings.

\section{Methodology}

The descriptive method with a survey technique was adopted. The research instrument is the "Teachers' attitude scale on the use of Language Laboratory" containing 38 items of 3 dimensions such as Affective, Cognitive and Conative aspects. The scale was given to the experts for their opinion. On the basis of their opinion, rewording, rephrasing, deletion and addition were done. The test re-test method of reliability was established and the reliability coefficient was found 0.7392 . For the quantitative data, a five-point Likert-scale was administered to investigate teachers' attitude towards the utilization of language laboratories. 60 teachers responded to the questionnaire. Teachers were asked to decide at which level they agreed with the statements from totally disagree to totally agree.

\section{Sample of the Study}

The study focuses on the attitude of the English language teachers towards the utilization of language laboratories to learn English. In order to conduct this study, 60 college teachers who are using language laboratory working in various colleges of Thanjavur and Tiruchy Districst were randomly chosen. For this study, data were collected by administering the questionnaire with 60 English teachers.

\section{Result and Discussion}

A rating system was used to determine positive and negative attitude in the respondents. In positive statement, a positive attitude is depicted in the Strong Agree (SA) and Agree (A) responses from the respondent. A negative attitude is depicted in the Strongly Disagree (SD) and Disagree (D) responses from the respondent. A U response depicts a neutral stand.

Table 1. Attitude of college teachers towards the utilization of language laboratories

Dimension I. Affective aspect

\begin{tabular}{llllcc}
\hline S.No Concept & $\begin{array}{l}\text { Strongly } \\
\text { agree }\end{array}$ & Agree & Neutral & $\begin{array}{c}\text { Disagree } \\
\text { Strongly } \\
\text { disagree }\end{array}$ \\
\hline & $\% \%$ & $\%$ & $\%$ & $\%$ & $\%$ \\
\hline Dimension I - Affective aspect & $\%$ & & & 1 \\
\hline $1 \quad$ While Using language lab students feel like & 6 & 34 & 16 & 3 \\
\hline
\end{tabular}




\begin{tabular}{|c|c|c|c|c|c|c|}
\hline & $\begin{array}{l}\text { they are interacting with a live native } \\
\text { speaker. }\end{array}$ & $10 \%$ & $57 \%$ & $27 \%$ & $5 \%$ & $2 \%$ \\
\hline \multirow[t]{2}{*}{2} & \multirow{2}{*}{$\begin{array}{l}\text { Language lab makes the task of learning } \\
\text { spoken English in the suitable environment. }\end{array}$} & 17 & 32 & 9 & 2 & 0 \\
\hline & & $28 \%$ & $53 \%$ & $15 \%$ & $3 \%$ & $0 \%$ \\
\hline \multirow[t]{2}{*}{3} & \multirow{2}{*}{$\begin{array}{l}\text { Language lab provides good working } \\
\text { environment for teachers }\end{array}$} & 6 & 32 & 17 & 4 & 1 \\
\hline & & $10 \%$ & $53 \%$ & $28 \%$ & $7 \%$ & $2 \%$ \\
\hline \multirow[t]{2}{*}{4} & \multirow{2}{*}{$\begin{array}{l}\text { Language lab usage frequently requires } \\
\text { teachers' assistance to accurately } \\
\text { complete his/her activity/lessons. }\end{array}$} & 1 & 6 & 17 & 30 & 6 \\
\hline & & $2 \%$ & $10 \%$ & $28 \%$ & $50 \%$ & $10 \%$ \\
\hline \multirow[t]{2}{*}{5} & \multirow{2}{*}{$\begin{array}{l}\text { Language lab usage by students is not } \\
\text { related to their leadership quality. }\end{array}$} & 8 & 24 & 17 & 9 & 2 \\
\hline & & $13 \%$ & $40 \%$ & $28 \%$ & $15 \%$ & $3 \%$ \\
\hline \multirow[t]{2}{*}{6} & \multirow{2}{*}{$\begin{array}{l}\text { Language lab usage provides supports to } \\
\text { individualized instruction. }\end{array}$} & 13 & 26 & 16 & 3 & 2 \\
\hline & & $22 \%$ & $43 \%$ & $27 \%$ & $5 \%$ & $3 \%$ \\
\hline \multirow[t]{2}{*}{7} & \multirow{2}{*}{$\begin{array}{l}\text { Language lab shall not provide an } \\
\text { immediate feedback to learners }\end{array}$} & 4 & 16 & 13 & 22 & 5 \\
\hline & & $7 \%$ & $27 \%$ & $22 \%$ & $37 \%$ & $8 \%$ \\
\hline \multirow[t]{2}{*}{8} & \multirow{2}{*}{$\begin{array}{l}\text { Teachers' role of monitoring is conducive } \\
\text { in language lab class. }\end{array}$} & 11 & 41 & 5 & 3 & 0 \\
\hline & & $18 \%$ & $68 \%$ & $8 \%$ & $5 \%$ & $0 \%$ \\
\hline \multirow[t]{3}{*}{9} & \multirow{2}{*}{$\begin{array}{l}\text { Language lab utilization helps the students } \\
\text { participate in Group discussion. }\end{array}$} & 15 & 35 & 6 & 1 & 3 \\
\hline & & $25 \%$ & $58 \%$ & $10 \%$ & $2 \%$ & $5 \%$ \\
\hline & Total \% & $16 \%$ & $50 \%$ & $21 \%$ & $10 \%$ & $3 \%$ \\
\hline
\end{tabular}

Teachers' have favourable attitude towards the utilization of language laboratories on the basis of affective aspect. In Table 1, Q1,Q2,Q3,Q5,Q6,Q8,\&Q9 are positive statements and Q4 \& Q7 are negative statements. In response to the statements Q1,Q2,Q3,Q5,Q6,Q8,\&Q9 as many as $87 \%$ of the respondents expressed favourable attitude and in response to the statements Q4,\& Q7, 74\% of the respondents expressed favourable attitude and this shows that the majority $(87 \%)$ of the respondents have a positive attitude towards the utilization of language laboratories on affective aspect.

Table 2. Attitude of college teachers towards the utilization of language laboratories

Dimension II. Cognitive aspect

\begin{tabular}{|c|c|c|c|c|c|c|}
\hline S.No & Concept & $\begin{array}{l}\text { Strongly } \\
\text { agree }\end{array}$ & Agree & Neutral & Disagree & $\begin{array}{l}\text { Strongly } \\
\text { disagree }\end{array}$ \\
\hline & & $\%$ & $\%$ & $\%$ & $\%$ & $\%$ \\
\hline \multicolumn{7}{|c|}{ Dimension II - Cognitive aspect } \\
\hline \multirow[t]{2}{*}{10} & \multirow{2}{*}{$\begin{array}{l}\text { Language lab enhances telephonic etiquette } \\
\text { of learners. }\end{array}$} & 8 & 30 & 18 & 3 & 1 \\
\hline & & $13 \%$ & $50 \%$ & $30 \%$ & $5 \%$ & $2 \%$ \\
\hline \multirow[t]{2}{*}{11} & \multirow{2}{*}{$\begin{array}{l}\text { Language lab hardly enhances the level of } \\
\text { Reading speed with accurate spelling }\end{array}$} & 10 & 22 & 22 & 4 & 2 \\
\hline & & $17 \%$ & $37 \%$ & $37 \%$ & $7 \%$ & $3 \%$ \\
\hline \multirow[t]{2}{*}{12} & \multirow{2}{*}{$\begin{array}{l}\text { Language lab usage frequently has } \\
\text { difficulty in recalling material from a } \\
\text { previous day's lessons. }\end{array}$} & 5 & 22 & 18 & 13 & 2 \\
\hline & & $8 \%$ & $37 \%$ & $31 \%$ & $22 \%$ & $3 \%$ \\
\hline 13 & Language lab usage brings learner closer to & 21 & 24 & 10 & 3 & 2 \\
\hline
\end{tabular}




\begin{tabular}{|c|c|c|c|c|c|c|}
\hline & real English Conversation. & $35 \%$ & $40 \%$ & $17 \%$ & $5 \%$ & $3 \%$ \\
\hline \multirow[t]{2}{*}{14} & \multirow{2}{*}{$\begin{array}{l}\text { Language lab supports the learner to rectify } \\
\text { errors immediately after speaking. }\end{array}$} & 15 & 27 & 13 & 4 & 1 \\
\hline & & $25 \%$ & $45 \%$ & $22 \%$ & $7 \%$ & $2 \%$ \\
\hline \multirow[t]{2}{*}{15} & \multirow{2}{*}{$\begin{array}{l}\text { Grammatical structures can never be } \\
\text { acquired by learners through utilization } \\
\text { of language lab. }\end{array}$} & 4 & 19 & 15 & 14 & 8 \\
\hline & & $7 \%$ & $32 \%$ & $25 \%$ & $23 \%$ & $13 \%$ \\
\hline \multirow[t]{2}{*}{16} & \multirow{2}{*}{$\begin{array}{l}\text { Language lab usage helps the learner use } \\
\text { appropriate vocabulary to convey their } \\
\text { intended meaning. }\end{array}$} & 12 & 31 & 12 & 3 & 2 \\
\hline & & $20 \%$ & $52 \%$ & $20 \%$ & $5 \%$ & $3 \%$ \\
\hline \multirow[t]{2}{*}{17} & \multirow{2}{*}{$\begin{array}{l}\text { Language lab usage improves fluency of } \\
\text { the students only after the completion of } \\
\text { their graduation }\end{array}$} & 4 & 16 & 12 & 27 & 1 \\
\hline & & $7 \%$ & $27 \%$ & $20 \%$ & $45 \%$ & $2 \%$ \\
\hline \multirow[t]{2}{*}{18} & \multirow{2}{*}{$\begin{array}{l}\text { Language lab provides practical knowledge } \\
\text { of the language for the learner rather } \\
\text { theoretical knowledge. }\end{array}$} & 25 & 25 & 6 & 2 & 2 \\
\hline & & $42 \%$ & $42 \%$ & $10 \%$ & $3 \%$ & $3 \%$ \\
\hline \multirow[t]{2}{*}{19} & \multirow{2}{*}{$\begin{array}{l}\text { There are technical drawbacks while using } \\
\text { Language lab. }\end{array}$} & 8 & 31 & 15 & 5 & 1 \\
\hline & & $13 \%$ & $52 \%$ & $25 \%$ & $8 \%$ & $2 \%$ \\
\hline \multirow[t]{2}{*}{20} & \multirow{2}{*}{$\begin{array}{l}\text { Language lab usage enhances the } \\
\text { presentation skill in English. }\end{array}$} & 11 & 41 & 5 & 1 & 2 \\
\hline & & $18 \%$ & $68 \%$ & $8 \%$ & $2 \%$ & $3 \%$ \\
\hline \multirow[t]{2}{*}{21} & \multirow{2}{*}{$\begin{array}{l}\text { Language lab provides learner to acquire } \\
\text { basic ICT skills. }\end{array}$} & 7 & 38 & 8 & 4 & 3 \\
\hline & & $12 \%$ & $63 \%$ & $13 \%$ & $7 \%$ & $5 \%$ \\
\hline \multirow[t]{2}{*}{22} & \multirow{2}{*}{$\begin{array}{l}\text { Language lab usage shall not help the } \\
\text { students to improve technical } \\
\text { communication. }\end{array}$} & 5 & 13 & 18 & 11 & 13 \\
\hline & & $8 \%$ & $22 \%$ & $30 \%$ & $18 \%$ & $22 \%$ \\
\hline \multirow[t]{2}{*}{23} & \multirow{2}{*}{$\begin{array}{l}\text { Language lab usage provides ample } \\
\text { knowledge about phrases among the } \\
\text { students. }\end{array}$} & 2 & 38 & 13 & 6 & 1 \\
\hline & & $3 \%$ & $63 \%$ & $22 \%$ & $10 \%$ & $2 \%$ \\
\hline \multirow[t]{2}{*}{24} & \multirow{2}{*}{$\begin{array}{l}\text { Language lab usage provides the students } \\
\text { ample knowledge about verbal expression. }\end{array}$} & 15 & 30 & 7 & 7 & 1 \\
\hline & & $25 \%$ & $50 \%$ & $12 \%$ & $12 \%$ & $2 \%$ \\
\hline \multirow[t]{2}{*}{25} & \multirow{2}{*}{$\begin{array}{l}\text { Language lab usage enhances the } \\
\text { achievement level of learners in the } \\
\text { academic area. }\end{array}$} & 8 & 31 & 12 & 7 & 2 \\
\hline & & $13 \%$ & $52 \%$ & $20 \%$ & $12 \%$ & $3 \%$ \\
\hline \multirow[t]{3}{*}{26} & \multirow{2}{*}{$\begin{array}{l}\text { Students find difficulty in sustaining } \\
\text { attention to listen when spoken directly. }\end{array}$} & 3 & 10 & 17 & 26 & 4 \\
\hline & & $5 \%$ & $17 \%$ & $28 \%$ & $43 \%$ & $7 \%$ \\
\hline & Total \% & $16 \%$ & $44 \%$ & $22 \%$ & $14 \%$ & $5 \%$ \\
\hline
\end{tabular}

Teachers' have favourable attitude towards the utilization of language laboratories on the basis of Cognitive aspect. 17 statements are there in Table 2. Out of which 13 are positive statements and 4 are negative statements. In Table 2, Q10,Q11,Q12,Q13,Q14,Q16,Q18,Q19,Q20,Q21,Q23,Q24\&Q259are positive statements and Q15,Q17,Q22\& Q26are negative statements. In response to the statements Q10,Q11,Q12,Q13,Q14,Q16,Q18,Q19,Q20,Q21,Q23,Q24\&Q259 as many as 94\% of the respondents expressed favourable attitude and in response to the statements Q15,Q17,Q22\& Q26, 70\% of the respondents expressed favourable attitude and this shows that the majority ( $82 \%)$ of the respondents have a favourable attitude towards the utilization of language laboratories on cognitive aspect. 
Table 3. Attitude of college teachers towards the utilization of language laboratories

Dimension III. Conative aspect

\begin{tabular}{llllllc}
\hline S.No Concept & $\begin{array}{l}\text { Strongly } \\
\text { agree }\end{array}$ & Agree & Neutral & Disagree & $\begin{array}{l}\text { Strongly } \\
\text { disagree }\end{array}$ \\
\hline & $\%$ & $\%$ & $\%$ & $\%$ & $\%$
\end{tabular}

\begin{tabular}{|c|c|c|c|c|c|c|}
\hline \multicolumn{7}{|c|}{ Dimension III - Conative aspect } \\
\hline \multirow[t]{2}{*}{27} & \multirow{2}{*}{$\begin{array}{l}\text { The students are active participants in } \\
\text { language lab class. }\end{array}$} & 14 & 28 & 15 & 2 & 1 \\
\hline & & $23 \%$ & $47 \%$ & $25 \%$ & $3 \%$ & $2 \%$ \\
\hline \multirow[t]{2}{*}{28} & \multirow{2}{*}{$\begin{array}{l}\text { Language lab usage shall not increase } \\
\text { the level of comprehension of learners. }\end{array}$} & 5 & 18 & 8 & 26 & 3 \\
\hline & & $8 \%$ & $30 \%$ & $13 \%$ & $43 \%$ & $5 \%$ \\
\hline \multirow[t]{2}{*}{29} & \multirow{2}{*}{$\begin{array}{l}\text { Language lab utilization alone develops } \\
\text { proper pronunciation among the } \\
\text { students. }\end{array}$} & 4 & 13 & 19 & 14 & 10 \\
\hline & & $7 \%$ & $22 \%$ & $32 \%$ & $23 \%$ & $17 \%$ \\
\hline \multirow[t]{2}{*}{30} & \multirow{2}{*}{$\begin{array}{l}\text { The Students needs more supervision } \\
\text { during language lab activity. }\end{array}$} & 4 & 3 & 13 & 32 & 8 \\
\hline & & $7 \%$ & $5 \%$ & $22 \%$ & $52 \%$ & $13 \%$ \\
\hline \multirow[t]{2}{*}{31} & Language lab usage enhances & 15 & 33 & 7 & 4 & 1 \\
\hline & $\begin{array}{l}\text { Concentration power and Understanding } \\
\text { concepts of the students. }\end{array}$ & $25 \%$ & $55 \%$ & $12 \%$ & $7 \%$ & $2 \%$ \\
\hline \multirow[t]{2}{*}{32} & \multirow{2}{*}{$\begin{array}{l}\text { Language lab usage develops proper } \\
\text { accent of native speakers among the } \\
\text { students. }\end{array}$} & 12 & 37 & 8 & 4 & 0 \\
\hline & & $20 \%$ & $62 \%$ & $13 \%$ & $7 \%$ & $0 \%$ \\
\hline \multirow[t]{2}{*}{33} & \multirow{2}{*}{$\begin{array}{l}\text { Language lab usage helps the students } \\
\text { learn about the stress and rhythm while } \\
\text { speaking. }\end{array}$} & 11 & 42 & 2 & 2 & 3 \\
\hline & & $18 \%$ & $70 \%$ & $3 \%$ & $3 \%$ & $5 \%$ \\
\hline \multirow[t]{2}{*}{34} & \multirow{2}{*}{$\begin{array}{l}\text { Language lab usage helps the students } \\
\text { learn about the intonation while speaking. }\end{array}$} & 14 & 34 & 8 & 4 & 0 \\
\hline & & $23 \%$ & $57 \%$ & $13 \%$ & $7 \%$ & $0 \%$ \\
\hline \multirow[t]{2}{*}{35} & \multirow{2}{*}{$\begin{array}{l}\text { Language lab provides required drill and } \\
\text { practice among the students to learn } \\
\text { spoken skill. }\end{array}$} & 12 & 33 & 11 & 1 & 3 \\
\hline & & $20 \%$ & $55 \%$ & $18 \%$ & $2 \%$ & $5 \%$ \\
\hline \multirow[t]{2}{*}{36} & \multirow{2}{*}{$\begin{array}{l}\text { Language lab is not for public speaking } \\
\text { skill of students. }\end{array}$} & 2 & 10 & 20 & 20 & 8 \\
\hline & & $3 \%$ & $17 \%$ & $33 \%$ & $33 \%$ & $13 \%$ \\
\hline \multirow[t]{2}{*}{37} & \multirow{2}{*}{$\begin{array}{l}\text { Language lab provides support to develop } \\
\text { students' self-confidence. }\end{array}$} & 14 & 34 & 6 & 5 & 1 \\
\hline & & $23 \%$ & $57 \%$ & $10 \%$ & $8 \%$ & $2 \%$ \\
\hline \multirow[t]{3}{*}{38} & \multirow{2}{*}{$\begin{array}{l}\text { Language lab usage helps students build } \\
\text { their future career. }\end{array}$} & 12 & 31 & 7 & 8 & 2 \\
\hline & & $20 \%$ & $52 \%$ & $12 \%$ & $13 \%$ & $3 \%$ \\
\hline & Total \% & $17 \%$ & $44 \%$ & $17 \%$ & $17 \%$ & $5 \%$ \\
\hline
\end{tabular}

Teachers' have favourable attitude towards the utilization of language laboratories on the basis of co- native aspect. In Table 3, 12 statements are there and of which 8 statements are positive and 4 are negative statements. In Table 3 Q27,Q31,Q32,Q33,Q34,Q35,Q37\&Q38 are positive statements and Q28,Q29,Q30\& Q36, are negative statements. In response to the statements Q27,Q31,Q32,Q33,Q34,Q35,Q37\&Q38 as many as 81\% of the respondents expressed favourable attitude and in response to the statements Q28,Q29,Q30\& Q36, 75\% of the respondents expressed favourable attitude and this shows that the majority $(78 \%)$ of the respondents have a favourable attitude towards the utilization of language laboratories on co-native aspect. The results of this study reveal that there is favourable attitude towards the utilization of Language laboratories in Cognitive (82\%), affective (87\%) and Co native (78\%) aspects. 


\section{Educational Implications}

All the colleges got to establish Language Laboratories which can be one of the greatest supplements for ESL Learners.

\section{Conclusion}

The social scenario in India has changed from 'Banish English' to 'Welcome English'. Now with the invent of multinational companies and the young professional getting a number of jobs with them need to know not only workable English but good presentational and communication skills too. Therefore, English has become a 'welcome' phenomenon all around. Blooming tourism industry, MNCs, BPOs, NGOs, missionaries and native speakers of English in India are demanding its youth to be proficient in English and the young people of India are aware of the usefulness of the target language. At college two factors come up as most important $-i$ ) to pass an examination and ii) to get a job. A very less percentage of students are indifferent to learning English at the college level. In spite of their desire to learn, they are not seen putting effort to learn. They are fearful of making mistakes. Their anxiety level is high whenever they are asked to read, write or speak English. This results in slow learning or in no learning.

Future of English in India is bright as we have got students who are aware of the usefulness of the target language. Traditional classroom makes the students in the class passive learners as the class remains teacher-centered. In spite of the traditional classroom, the multimedia Language lab provides the task-based communicative curriculum and humanistic approach to teach English.

The language laboratory, long a bulwark of programmed instruction (i.e., drill and repeat exercises), is now experiencing re- evaluation by teachers for its potential as an instructional tool (Stone, 1991). However, this study would like to suggest some directions for teachers' reference. The teachers should prepare themselves for the use of modern computer technology. Foreign language training will not always take place in a traditional classroom. With the help of a setting such as a multimedia lab, foreign language training will be more efficient. Teachers should have the clear idea of how a traditional classroom is different from a multimedia lab. On the whole, the primary objective now is communicative fluency rather than linguistic accuracy which can be implemented through the language laboratory.

\section{References}

Agnihotri, R.K., \& Khanna, A.L. (1994). Second Language Acquisition: Socio-cultural and Linguistics. Aspects of English in India. New Delhi/Thousand Oaks/London: Sage Publications.

Baltra, A. (1986). Computer assisted language learning: What is it all about?. Paper presented at a conference at the University of California, Irvine.

Baltra, A. (1987). Cooperative Learning, communicative software, and teachers as stage directors. Paper presented at the Annual Meeting of the Teachers of English to Speakers of Other Languages, Miami, FL.

Brown, H.D. (1987). Principles of Language Learning and Teaching. MA: Addison-Wesley Publishing Company.

Brumfit, C., \& Johnson, K. (1979). The Communicative Approach to Language Teaching. New York: Oxford University Press (Ed.).

Gardner, R.C., \& Lamber, W.E. (1972). Attitudes and motivation in Second Language Learning.

Hymes, D. (1972). On Communicative Competence. In J. B. Pride and J. Holmes (Eds.), Sociolinguistics. Harmondswortth: Penguin.

Kresan, S. (1981). Second Language Acquisition and Second Language Learning, Oxford: Pergamon Press.

Linder, C. (Ed.). (1977). Oral communication testing: A handbook for the foreign language teacher. Lincolnwood, IL: National Textbook Co.

Littlewood, W. (1981). Communicative Language Teaching. New York: Cambridge University Press.

Meenakshi, H.V. (2005). Learner's Attitude and Its Impact on Language Learning.

Nattinger, J.R. (1984). Communicative Language Teaching: A New Metaphor. TESOL Quarterly.

Nunan, D. (1987). Communicative Language Teaching: Making it work. ELT Journal.

Nunan, D. (1989). Designing Tasks for the Communicative Classroom. New York: Cambridge University Press.

Richards, J.C., \& Rodgers, T.S. (1986). Approaches and Methods in language Teaching: A Descriptions and Analysis. New York: Cambridge University Press. 
Rivers, W. (Ed.). (1987). Interactive language teaching. NY: Cambridge University Press.

Rossner, R. (1988). Materials for Communicative Language Teaching and Learning. Annual Review of Applied Linguistics.

Savingnon, S.J. (1983). Communicative Competence: Theory and Classroom Practice. Reading. Mass: Addison-Wesley Publishing Company.

Smriti, S. (2014), Language Laboratory: Purposes and Shortcomings.

Stone, L. (1988). Task-based activities: A communicative approach to language laboratory use. Philadelphia, PA: International Association for Learning Laboratories.

Yalden, J. (1983). The Communicative Syllabus: Evolution, Design and Implementation. Oxford: Pergamon Press.

\section{Copyrights}

Copyright for this article is retained by the author(s), with first publication rights granted to the journal.

This is an open-access article distributed under the terms and conditions of the Creative Commons Attribution license (http://creativecommons.org/licenses/by/4.0/). 